Association for Information Systems AIS Electronic Library (AISeL)

ICIS 1983 Proceedings

International Conference on Information Systems

1983

\title{
An Examination of Work-Related Correl ates of Job Satisfaction in Programmer/Analysts
}

David K. Goldstein

Sloan School of Management, MIT

John F. Rockart

Sloan School of Management, MIT

Follow this and additional works at: http://aisel.aisnet.org/icis1983

\section{Recommended Citation}

Goldstein, David K. and Rockart, John F., "An Examination of Work-Related Correl ates of Job Satisfaction in Programmer/Analysts" (1983). ICIS 1983 Proceedings. 21.

http://aisel.aisnet.org/icis1983/21

This material is brought to you by the International Conference on Information Systems (ICIS) at AIS Electronic Library (AISeL). It has been accepted for inclusion in ICIS 1983 Proceedings by an authorized administrator of AIS Electronic Library (AISeL). For more information, please contact elibrary@aisnet.org. 


\author{
David K. Goldstein \\ John F. Rockart \\ Sloan School of Management, MIT
}

\begin{abstract}
Even though industrial and organizational psychologists have accumulated a great deal of knowledge about job satisfaction, few MIS researchers have applied this knowledge to the study of the fob satisfaction of programmer/analysts. One of the most notable exceptions to this oversight is the study conducted by Cougar and Zawacki (1981). These researchers examined the relationship between programmer/analysts' feelings about their $j$ obs and one set of work-related correlates of job satisfaction - correlates of satisfaction stemming from the work itself. Specifically, they used Hackman and 01 dham's (1976, 1980) Job Characteristic Model (JCM) to study the relationshtp between the tasks carried out by programmer/analysts and the programmer/analysts' feelings about their jobs.
\end{abstract}

This research examines two sets of variables that can be added to the JCM and can measure some work-related correlates of job satisfaction not considered by Couger and Zawacki. One set of variables - role perceptions - measures the amount of conflict and ambiguity in a worker's job (Kahn, Wolfe, Quinn, Stroek, and Rosenthal, 1964). Researchers have found high levels of conflict and ambiguity among workers who have a great deal of contact with people in other groups within the organization. Since contact with information systems users is often an important part of programmer/analysts jobs, role perceptions should be significant correlates of job satisfaction in programmer/analysts. The second set of variables measures the quality of leadership provided by the worker's supervisor and peers (Bowers and Seashore, 1966). Leadership characteristics should also be important in the study of programmer/analysts' jobs, because of the amount of team work needed in developing information systems.

The survey described below examines the relative importance of these three sets of independent varfables - job characteristics, role perceptions, and leadership characteristics - as correlates of job satisfaction in programmer/analysts. It is hypothesized that each of the in-

*This paper is forthcoming in the MIS Quarterly. 
dependent variables will be significant correlated of job satisfaction. Further, it is hypothesized that the addition of role perceptions and leadership characteristics to job characteristics will significantly increase our understanding of work-related correlates of job satisfaction.

To test these hypotheses, a survey of 188 programmer/analysts was carried out. The subjects cam from two insurance companies and two industrial companies, each with a staff of over 100 programmer/analysts. The subject completed a questionnalre that contained measures for each of the independent variables and for job satisfaction.

Correlation and regression analyses were performed on the survey data. The correlation analysis indicated that each of the job characteristics, role perceptions, and leadership characteristics correlated significantly. With job satisfaction. In general, the role perceptions correlated more highly with the satisfaction variables than either the leadership characteristics or the job characteristics.

Multiple regression analyses were performed to examine the amount of variance in job satisfaction explained by each of the three sets of independent variables. The job characteristics alone explained $39 \%$ of the variance in job satisfaction. The role perceptions alone explained $34 \%$ of the variance, and the leadership characteristics alone explained $25 \%$ of the variance in satisfaction. Further analysis indicated that using job characteristics in a base regression and then adding role perceptions and leadership characteristics, efther individualiy or together, significantly increased the explained variance in job satisfaction. The addition of both sets of variables increased the explained variance in job satisfaction from $39 \%$ to $50 \%$.

The main conclusion of this research is that extensions are needed to the JCM to better understand the work-rel ated correlates of job satisfaction in programmer/analysts. This conclusion has important implications for researchers and practitioners interested in redesigning programmer/analysts' jobs. Work redesigners must not focus solely on modifying the tasks performed by programmer/analysts. In addition, they must examine the interactions between information systems users and programmer/analysts that could affect role confict and role ambiuity. Further, they must consider the quality of leadership provided by information systems managers and the programmer/analysts' co-workers and how improvements in this area can lead to higher job satisfaction. 


\section{REFERENCES}

Bowers, D.G. and Seashore, S.E. "Predicting Organizational Effectiveness with a Four-Factor Theory of Leadership," Administrative Science Quarterly Vol ume 11, Number 2, September 1966, pp. 238-263.

Couger, D. and Zawacki, R. Motivating and Managing Computer Personnel, John Wfley and Sons, New York, New York, 1981.

Hackman, J.R. and 01 dham, G.R. "Motivation Through the Design of
Work: A Test of a Theory," Organizational Behavior and Human Performance, Vol ume 16 , Number 2 , August 1976, pp. 25-279.

Hackman, J.R. and 01 dham, G.R. Work Redesign, Addison Wesley, Reading, Massachusetts, 1980.

Kahn, R.L., Wolfe D., Quinn R., Snoek J.D., and Rosenthal R. Organizational Stress: Studies in Role Conflict and Role Ambiguity, John Wiley and Sons, New York, New York, 1964 . 